\title{
Neural-cadherin expression associated with angiogenesis in non-small-cell lung cancer patients
}

\author{
T Nakashima', C Huang*,', D Liu', K Kameyama', D Masuya', S Kobayashi ${ }^{2}$, M Kinoshita ${ }^{3}$ and H Yokomise' \\ 'Second Department of Surgery, Kagawa Medical University, I 750-I Miki-cho, Kita-gun, Kagawa 76 I-0793, Japan; '2Department of Pathology, Kagawa \\ Medical University, Kagawa, Japan; ${ }^{3}$ Gene-Diagnostic Center, Otsuka Assay Laboratory, Otsuka Pharmaceutical Co., Ltd., Tokushima, Japan
}

\begin{abstract}
An immunohistochemical analysis for $\mathrm{E}$ (epithelial)-cadherin and $\mathrm{N}$ (neural)-cadherin expression in relation to tumour angiogenesis was performed in 150 patients with non-small-cell lung cancer (NSCLC). In all, 7I carcinomas (47.3\%) were E-cadherin-negative. Epithelial-cadherin-negative tumours had lymph node metastases significantly more frequently than E-cadherin-positive tumours $(P=0.0100)$. On the other hand, 46 carcinomas (30.7\%) were $\mathrm{N}$-cadherin-positive. Regarding tumour vascularity, there was no significant correlation between E-cadherin expression and tumour vascular. In contrast, the frequency of hypervascular tumours was significantly higher for $\mathrm{N}$-cadherin-positive carcinomas than for $\mathrm{N}$-cadherin-negative carcinomas $(P=0.0373)$. Regarding prognosis, the 5-year survival rate of patients with E-cadherin-negative NSCLCs was significantly lower than that of patients with E-cadherinpositive NSCLCs $(P=0.0146)$. In contrast, of the patients with large cell carcinomas, the 5 -year survival rate of patients with $\mathrm{N}$-cadherin-positive tumours was significantly lower than that of patients with $\mathrm{N}$-cadherin-negative tumours $(P=0.00 \mathrm{I} 3)$. A multivariate analysis demonstrated that E-cadherin status $(P=0.0339)$ and tumour vascularity $(P=0.0295)$ were significant indicators for survival. In conclusion, E-cadherin expression and tumour vascularity are significant prognostic factors of NSCLC patients. Furthermore, $\mathrm{N}$-cadherin expression is associated with tumour angiogenesis, and its expression is one of prognostic factors of patients with large cell carcinomas. Thus, $\mathrm{N}$-cadherin also might play a specific role in undifferentiated large cell carcinomas. British Journal of Cancer (2003) 88, I727-1733. doi:I0.1038/sj.bjc.6600955 www.bjcancer.com (C) 2003 Cancer Research UK
\end{abstract}

Keywords: N-cadherin; E-cadherin; angiogenesis; immunohistochemistry; lung cancer

It is widely accepted that malignant tumours are caused by the accumulation of genetic alterations, which could reflect the biological behaviour of tumours (Cordon-Cardo, 1995). In particular, metastasis is specific for malignant tumours, and the control of tumour metastasis is one of the most important problems in the design of therapies for cancer patients. Its initial step is the escape of cells from the primary tumours, which is considered to be dependent on the status of various adhesion molecules, including cadherins, integrins, selectins, and the immunoglobulin superfamily (Pignatelli and Vessey, 1994).

Cadherins are transmembrane glycoproteins that function for calcium-dependent homophilic cell-cell adhesion (Takeichi, 1991). They include several subclasses, such as E (epithelial)cadherin, $\mathrm{N}$ (neural)-cadherin, $\mathrm{P}$ (placental)-cadherin and so on. Among these cadherins, E-cadherin is widely expressed in normal epithelial tissues and is linked to the actin cytoskeleton by the catenins (Aberle et al, 1996). Experimental studies have demonstrated that E-cadherin acts as a metastatic suppressor gene (Frixen et al, 1991; Mbalaviele et al, 1996). Previous clinical studies also have revealed that the functional disruption of E-cadherin is associated with tumour dedifferentiation and metastasis in various human cancers including non-small-cell lung cancers (NSCLCs) (Shibanuma et al, 1998; Sulzer et al, 1998; Liu et al, 2001).

*Correspondence: Dr C Huang; E-mail: chuang@kms.ac.jp

Received 13 January 2003; accepted 25 February 2003
On the other hand, $\mathrm{N}$-cadherin is expressed mainly in the nervous system and in mesenchymal cells, such as myocytes and fibroblasts (Hatta et al, 1987). And its expression is associated with a variety of morphogenic events and angiogenesis during development (Hatta and Takeichi, 1986; Blaschuk and Rowlands, 2000). Thus, the function of $\mathrm{N}$-cadherin is suggested to be different from that of E-cadherin. Furthermore, recent studies have demonstrated that $\mathrm{N}$-cadherin expression in tumour tissues is associated with tumour progression, such as epithelial-mesenchymal transitions (Birchmeier et al, 1996), motility, and metastasis (Nieman et al, 1999; Hazan et al, 2000; Li et al, 2001). In addition, several studies on human cancers have reported the presence of the cadherin switching, from E-cadherin to N-cadherin (Hsu et al, 1996; Tomita et al, 2000).

However, despite of the accumulation of these results regarding $\mathrm{N}$-cadherin, only a few clinical studies on $\mathrm{N}$-cadherin expression in human cancers were reported (Yanagimoto et al, 2001), and its true function in human cancers is still unknown. Therefore, to clarify the function of N-cadherin in NSCLCs, we performed a retrospective clinical study on $\mathrm{N}$-cadherin expression and $\mathrm{E}$ cadherin expression by immunohistochemistry. In addition, because the tumour angiogenesis was also reported to be essential to tumour growth and metastasis (Folkman, 1990, 1995), we evaluated intratumoural microvessel density (IMD) using antiCD34 monoclonal antibody to study the correlation between $\mathrm{N}$ cadherin expression and tumour angiogenesis (Matsuyama et al, 1998). 


\section{MATERIALS AND METHODS}

\section{Clinical characteristics of patients}

From January 1993 to February 1999, NSCLC patients who underwent surgery at the Second Department of Kagawa Medical University were studied. Tumour-node-metastasis (TNM) staging designations were made according to the international postsurgical pathological staging system. Since advanced stage lung cancer (stage IV) involves several complicated factors and these primary tumour specimens are difficult to obtain by surgical resection, these patients were excluded from this study. In total, 150 patients with lung cancer up to stage IIIB, which included 86 patients with adenocarcinoma, 50 patients with squamous cell carcinoma, and 14 patients with large cell carcinoma which is defined as undifferentiated NSCLC without the component of squamous cell carcinoma, adenocarcinoma (Travis et al, 1999), were investigated. The patients' clinical records and histopathological diagnoses were fully documented. This report includes follow-up data as of 10 September 2002. The median follow-up period for all patients was 41.1 months.

\section{Immunohistochemical staining of E-cadherin, $\mathrm{N}$-cadherin, and CD34}

We used a mouse polyclonal antibody for E-cadherin (Clone HECD-1, Takara, Otsu, Japan) diluted at 1:400, a mouse monoclonal antibody for $\mathrm{N}$-cadherin (clone 32, BD Bioscience, Franklin Lakes, NJ, USA) diluted at $1: 1000$, and a mouse monoclonal antibody for CD34 (NU-4A1, Nichirei Corporation, Tokyo, Japan) diluted at $1: 10$.

Formalin-fixed paraffin-embedded tissue specimens were cut into $4-\mu \mathrm{m}$ sections and mounted on poly-L-lysine-coated slides. The sections were deparaffinised and rehydrated. The slides were then heated in a microwave for $10 \mathrm{~min}$ in a $10-\mu \mathrm{moll}^{-1}$ citrate buffer solution at $\mathrm{pH} 6.0$, and cooled to room temperature for $20 \mathrm{~min}$. After quenching the endogenous peroxidase activity with $0.3 \% \mathrm{H}_{2} \mathrm{O}_{2}$ (in absolute methanol) for $30 \mathrm{~min}$, the sections were blocked for $2 \mathrm{~h}$ at room temperature with $5 \%$ bovine serum albumin. Subsequently, duplicate sections were incubated overnight with the primary specific antibodies for E-cadherin, $\mathrm{N}$ cadherin, and CD34, respectively. The slides were then incubated for $1 \mathrm{~h}$ with biotinylated anti-mouse IgG (Vector Laboratories Inc., Burlingame, CA, USA). The sections were incubated with the avidin-biotin-peroxidase complex (Vector Laboratories Inc.) for $1 \mathrm{~h}$, and the antibody binding was visualised with $3,3^{\prime}$-diaminobenzidine tetrahydrochloride. Finally, the sections were counterstained with Mayer's haematoxylin (Figure 1). Normal bronchus epithelium and normal mucosal glands within the tumour sections were used as positive internal controls for staining of E-cadherin. Sections of resected lung tumours known to express $\mathrm{N}$-cadherin were used as positive controls for staining of $\mathrm{N}$-cadherin. Sections incubated with normal mouse IgG served as negative reaction controls for staining of E-cadherin and $\mathrm{N}$-cadherin.

All of the immunostained sections were reviewed by two pathologists who had no knowledge of the patients' clinical status. Patients with contradictory scores were reevaluated jointly on a second occasion and consensus was reached. For the evaluation of immunostaining of E-cadherin and $\mathrm{N}$-cadherin, in cases with multiple areas of low intensity, five areas selected at random were scored; in sections where all of the staining appeared intense, one random field was selected. At least 200 tumour cells were scored per $\times 40$ field. When $\geqslant 50 \%$ of the tumour cells in a given specimen were positively stained for E-cadherin, the sample was classified as E-cadherin-positive. When $<50 \%$ of the cells were stained, it was classified as E-cadherin-negative. In addition, when $\geqslant 20 \%$ of the tumour cells in a given specimen were positively stained for $\mathrm{N}$-cadherin, the sample was classified as $\mathrm{N}$-cadherin- positive. When $<20 \%$ of the cells were stained, it was classified as $\mathrm{N}$-cadherin-negative.

For microvessel quantification, the three most highly vascularised areas detected by CD34 immunostaining were initially selected under the $\times 40$ field, and a $\times 200$ field $\left(0.785 \mathrm{~mm}^{2}\right.$ per field) was used to count vessels in each of these areas (Figure 1F). Vessels of a calibre larger than approximately eight red blood cells and vessels with thick muscular walls were excluded from the count. Single endothelial cells or clusters of endothelial cells, with or without lumen, were considered to be individual vessels. Finally, the average of three $\times 200$ field counts was recorded as the IMD. Tumours with IMD $\geqslant 90$ were classified as hypervascular, while tumours with IMD $<90$ were classified as hypovascular.

\section{Statistical analysis}

The overall cancer-specific survival was defined from the date of the operation to the date of cancer-related death. The statistical differences in E-cadherin and $\mathrm{N}$-cadherin expression in relation to several other clinical and pathological parameters including IMD were assessed by the $\chi^{2}$ test and the $t$-test. The Kaplan-Meier method was used to estimate the probability of overall survival as function of time, and differences in the survival of subgroups of patients were compared with Mantel's log-rank test. Cox's proportional-hazards regression model was used to study the effects of different variables on survival. All $P$-values were based on two-tailed statistical analysis and a $P$-value $<0.05$ was considered to indicate statistical significance.

\section{RESULTS}

\section{Epithelial-cadherin expression in NSCLCs}

Normal bronchus epithelium and normal mucosal glands had positive membranous expression of E-cadherin. Intratumoural E-cadherin staining also appeared in the form of a membranous staining pattern, with or without cytoplasmic staining (Figure 1A, B). Of the 150 tumours studied, 79 carcinomas (52.7\%) were E-cadherin-positive, and 71 carcinomas $(47.3 \%)$ were E-cadherinnegative (Table 1). Of the 86 adenocarcinomas, 36 tumours (41.9\%) were E-cadherin-negative. Of the 50 squamous cell carcinomas, 25 tumours (50.0\%) were E-cadherin-negative. Of the 14 large cell carcinomas, 10 tumours $(71.4 \%)$ were E-cadherinnegative. The frequency of E-cadherin-negative tumours was likely to be greater in large cell carcinoma than any other tumour histology. Furthermore, E-cadherin-negative tumours had lymph node metastases significantly more frequently than E-cadherinpositive tumours $(39.4$ vs $20.3 \%, P=0.0100)$ (Table 1$)$. In addition, advanced stage tumours were significantly more frequent in E-cadherin-negative tumours than in E-cadherin-positive tumours (53.5 vs $32.9 \%, P=0.0378$ ).

\section{Neural-cadherin expression in NSCLCs}

Intratumoural $\mathrm{N}$-cadherin staining also appeared in the form of a membranous staining pattern, with or without cytoplasmic staining. Of the 150 tumours, 46 carcinomas (30.7\%) were $\mathrm{N}$-cadherin-positive, and 104 carcinomas $(69.3 \%)$ were $\mathrm{N}$-cadherinnegative (Figure $1 \mathrm{C}-\mathrm{E}$ and Table 1). Of the 86 adenocarcinomas, 31 tumours $(36.0 \%)$ were $\mathrm{N}$-cadherin-positive. Of the 50 squamous cell carcinomas, 10 tumours $(20.0 \%)$ were $\mathrm{N}$-cadherin-positive. Of the 14 large cell carcinomas, five tumours (35.7\%) were $\mathrm{N}$-cadherin-positive. There was no significant relation between $\mathrm{N}$-cadherin expression status and tumour histology. In addition, there was no significant relation between $\mathrm{N}$-cadherin expression status and other patient prognostic factors, such as tumour status, nodal status, pathological stage, and tumour differentiation (Table 1). 


\section{Relation between E-cadherin expression and N-cadherin expression}

With respect to 150 NSCLCs, 28 tumours (35.4\%) were Ncadherin-positive among the 79 E-cadherin-positive carcinomas, while 18 tumours $(25.4 \%)$ were $\mathrm{N}$-cadherin-positive among the 71 E-cadherin-negative carcinomas. There was no significant relation
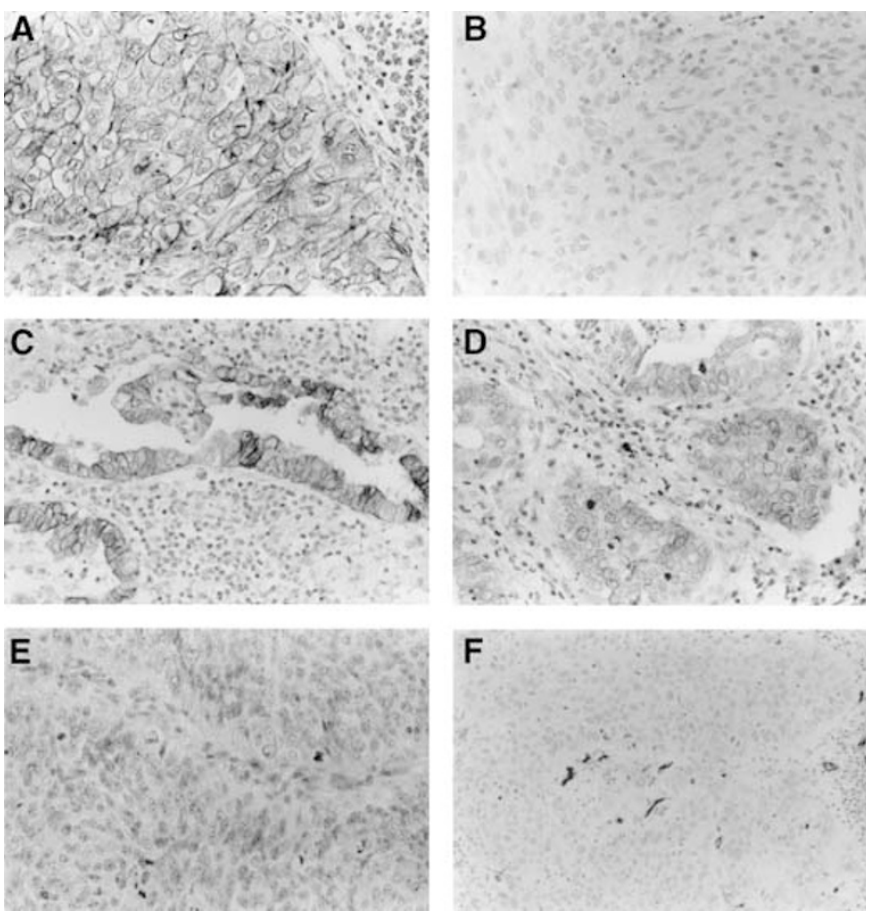

Figure I Immunohistochemical staining of human NSCLC tissues using the avidin-biotin-peroxidase complex procedure (original magnification, $\times$ 100). (A) An E-cadherin-positive carcinoma. (B) An E-cadherin-negative carcinoma. (C). (D) N-cadherin-positive carcinomas. (E) A N-cadherinnegative carcinoma. (F) Intratumoural microvessel detected by anti-CD34 antibody in a carcinoma. between $\mathrm{N}$-cadherin expression and E-cadherin expression in NSCLCs. However, regarding 14 undifferentiated large cell carcinomas, only one tumour $(25.0 \%)$ was $\mathrm{N}$-cadherin-positive among four E-cadherin-positive tumours, while four tumours (40.0\%) were $\mathrm{N}$-cadherin-positive among $10 \mathrm{E}$-cadherin-negative tumours.

\section{Tumour vascularity in NSCLCs}

The IMD in the 150 NSCLCs ranged from 24.0. to 394.7, with a mean of $110.6 \pm 65.3$. In all, 82 carcinomas $(54.7 \%)$ were hypervascular, and 68 carcinomas $(45.3 \%)$ were hypovascular (Table 1). Regarding tumour histology, of the 86 adenocarcinomas, 58 tumours $(67.4 \%)$ were hypervascular. Of the 50 squamous cell carcinomas, 17 tumours (34.0\%) were hypervascular. Of the 14 large cell carcinomas, seven tumours $(50.0 \%)$ was hypervascular. The frequency of hypervascular tumours in adenocarcinomas was significantly greater than that in squamous cell carcinomas $(P=0.0007)$. However, there were no significant correlation between IMD and other prognostic factors, such as tumour status, nodal status, tumour differentiation.

\section{Relation between cadherin expressions and tumour vascularity}

With respect to E-cadherin status, of the 79 E-cadherin-positive carcinomas, 46 tumours (58.3\%) were hypervascular; of the 71 E-cadherin-negative carcinomas, 36 tumours (50.7\%) were hypervascular. There was no significant correlation between E-cadherin expression and tumour vascularity.

Regarding N-cadherin status, of the $46 \mathrm{~N}$-cadherin-positive carcinomas, 31 tumours (67.4\%) were hypervascular; of the 104 $\mathrm{N}$-cadherin-negative carcinomas, 51 tumours (49.0\%) were hypervascular. The frequency of hypervascular tumours was significantly higher for $\mathrm{N}$-cadherin-positive carcinomas than for $\mathrm{N}$-cadherin-negative carcinomas $(P=0.0373$; Figure 2$)$. With respect to tumour histology, of the 86 adenocarcinomas, the frequencies of hypervascular tumours were $74.2 \%$ in N-cadherinpositive carcinomas, $63.6 \%$ in $\mathrm{N}$-cadherin-negative carcinomas. Of the 50 squamous cell carcinomas, the frequencies of hypervascular tumours were $50.0 \%$ in $\mathrm{N}$-cadherin-positive carcinomas, $30.0 \%$ in

Table I Distribution of I50 NSCLC patients according to E-cadherin, N-cadherin status, and tumour vascularity

\begin{tabular}{|c|c|c|c|c|c|c|c|c|c|c|}
\hline \multirow[b]{2}{*}{ Variables } & \multirow[b]{2}{*}{$n$} & \multicolumn{3}{|c|}{ E-cadherin } & \multicolumn{3}{|c|}{$\mathbf{N}$-cadherin } & \multicolumn{3}{|c|}{ Tumour vascularity } \\
\hline & & Positive & Negative & $P$-value & Positive & Negative & $P$-value & Hypervascular & Hypovascular & $P$-value \\
\hline \multicolumn{11}{|l|}{ Tumour status } \\
\hline TI & 62 & 36 & 26 & \multirow[t]{4}{*}{0.1629} & 20 & 42 & \multirow[t]{4}{*}{0.9245} & 39 & 23 & \multirow[t]{4}{*}{0.0540} \\
\hline $\mathrm{T} 2$ & 50 & 27 & 23 & & 16 & 34 & & 20 & 30 & \\
\hline T3 & 7 & I & 6 & & 2 & 5 & & 3 & 4 & \\
\hline T4 & 31 & 15 & 16 & & 8 & 23 & & 20 & || & \\
\hline \multicolumn{11}{|l|}{ Nodal status } \\
\hline No & 106 & 63 & 43 & \multirow[t]{2}{*}{0.0100} & 35 & 71 & \multirow[t]{2}{*}{0.3265} & 58 & 48 & \multirow[t]{2}{*}{0.9847} \\
\hline NI, N2, N3 & 44 & 16 & 28 & & || & 33 & & 24 & 20 & \\
\hline \multicolumn{11}{|l|}{ Pathological stage } \\
\hline Stage I & 86 & 53 & 33 & \multirow[t]{4}{*}{0.0378} & 28 & 58 & \multirow[t]{4}{*}{0.3198} & 45 & 41 & \multirow[t]{4}{*}{0.6656} \\
\hline Stage ॥ & 15 & 4 & 11 & & 3 & 12 & & 8 & 7 & \\
\hline Stage IIIA & 18 & 7 & 11 & & 8 & 10 & & 9 & 9 & \\
\hline Stage IIIB & 31 & 15 & 16 & & 7 & 24 & & 20 & $1 \mid$ & \\
\hline \multicolumn{11}{|l|}{ Differentiation } \\
\hline Well & 54 & 32 & 22 & \multirow[t]{3}{*}{0.2815} & 17 & 37 & \multirow[t]{3}{*}{0.9859} & 37 & 17 & \multirow[t]{3}{*}{0.0375} \\
\hline Moderately & 50 & 27 & 23 & & 15 & 35 & & 23 & 27 & \\
\hline Poorly & 46 & 20 & 26 & & 14 & 32 & & 22 & 24 & \\
\hline \multicolumn{11}{|l|}{ Histology } \\
\hline Adenocarcinoma & 86 & 50 & 36 & \multirow[t]{4}{*}{0.1088} & 31 & 55 & \multirow[t]{4}{*}{0.1344} & 58 & 28 & \multirow[t]{4}{*}{0.0070} \\
\hline Squamous cell carcinoma & 50 & 25 & 25 & & 10 & 40 & & 17 & 33 & \\
\hline Large cell carcinoma & 14 & 4 & 10 & & 5 & 9 & & 7 & 7 & \\
\hline Total number of patients & 150 & 79 & 71 & & 46 & 104 & & 82 & 68 & \\
\hline
\end{tabular}


$\mathrm{N}$-cadherin-negative carcinomas. Of the 14 large cell carcinomas, the frequencies of hypervascular tumours were $60.0 \%$ in $\mathrm{N}$ cadherin-positive carcinomas, $44.4 \%$ in $\mathrm{N}$-cadherin-negative carcinomas.

\section{Overall survival of NSCLC patients in relation to E-cadherin status, $\mathrm{N}$-cadherin status, and tumour vascularity}

The 5-year survival rates of 150 NSCLC patients according to E-cadherin status, $\mathrm{N}$-cadherin status and tumour vascularity are shown in Table 2. With respect to E-cadherin status, the 5-year survival rate of patients with E-cadherin-negative NSCLCs was significantly lower than that of patients with E-cadherin-positive NSCLCs (45.4 vs 64.4\%, $P=0.0146$, Figure 3A). Especially, the 5 -year survival rate of patients with E-cadherin-negative T1 tumours was significantly lower than that of patients with E-cadherinpositive T1 tumours (79.1 vs $59.8 \%, P=0.0328$, Figure 3B).

In contrast, there was no significant difference in the 5-year survival rate between patients with $\mathrm{N}$-cadherin-positive NSCLCs and patients with N-cadherin-negative NSCLCs (59.6 vs 54.0\%).

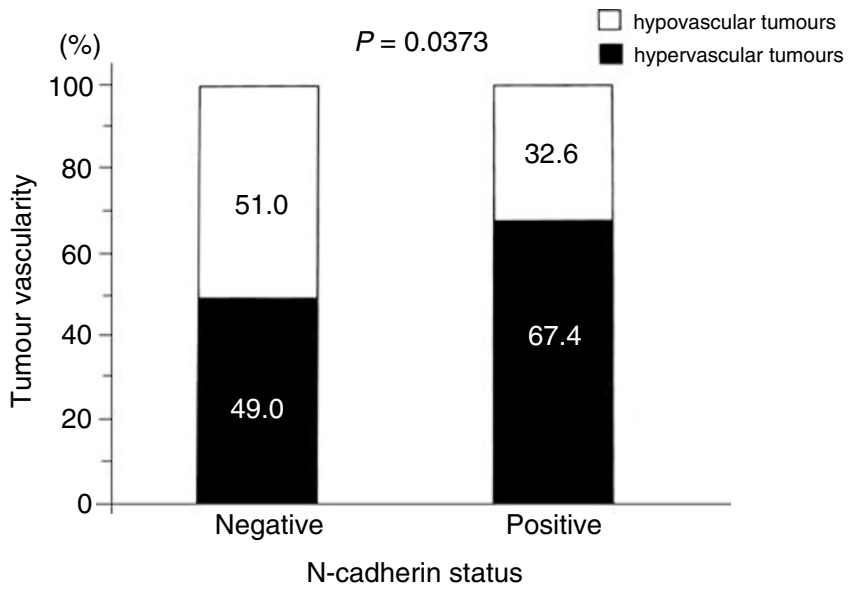

Figure 2 Tumour vascularity in relation to N-cadherin status in NSCLCs.
However, of the 14 patients with undifferentiated large cell carcinomas, the 5-year survival rate of patients with $\mathrm{N}$-cadherinpositive tumours was significantly lower than that of patients with $\mathrm{N}$-cadherin-negative tumours ( 0.0 vs $55.6 \%, P=0.0013$, Figure $3 \mathrm{C})$.

With respect to tumour vascularity, the 5-year survival rate of patients with hypervascular NSCLCs was significantly lower than that of patients with hypovascular NSCLCs (50.8 vs 62.2\%, $P=0.0378$, Figure 3D). Regarding tumour histology, the 5-year survival rate of patients with hypervascular squamous cell carcinomas was significantly lower than that of patients with hypovascular squamous cell carcinomas (44.1 vs $68.3 \%$, $P=0.0349$ ).

A multivariate analysis using Cox proportional-hazards regression model was performed to evaluate prognostic factors for NSCLC patients, as shown in Table 3. Epithelial-cadherin status (hazard ratio $=1.736, P=0.0339$ ) and tumour vascularity (hazard ratio $=1.785, P=0.0295$ ) were significant indicators for survival of NSCLC patients. With respect to tumour histology, tumour vascularity was also a significant indicator for survival of patients with squamous cell carcinomas (hazard ratio $=5.529, P=0.0053$ ), and patients with large cell carcinomas (hazard ratio $=24.815$, $P=0.0312)$

\section{DISCUSSION}

The cadherins are members of a large family of transmembrane glycoproteins that mediate calcium dependent, homophilic cellcell adhesion and play an important role in the maintenance of normal tissue architecture (Takeichi, 1990). Among this family, Ecadherin is widely expressed in normal epithelial cells. Numerous studies have demonstrated the importance of the E-cadherin/ catenin complex in maintaining the normal phenotype of epithelial cells (Frixen et al, 1991; Mbalaviele et al, 1996). Although the actual mechanisms responsible for its functional disruption in human cancers are still not fully clarified (Blaschuk et al, 1995; Nawrocki et al, 1998), their dysfunction causes dedifferentiation and invasive tumours. In a previous experimental study, invasive fibroblastic-like carcinoma cells could be converted to a noninvasive phenotype by transfection of E-cadherin cDNA (Frixen et al, 1991). Previous clinical studies in human cancers, including

Table 2 Five-year survival rate of I50 NSCLC patients according to E-cadherin, N-cadherin status, and tumour vascularity

\begin{tabular}{|c|c|c|c|c|c|c|c|c|c|}
\hline Variables & \multicolumn{3}{|c|}{ E-cadherin } & \multicolumn{3}{|c|}{ N-cadherin } & \multicolumn{3}{|c|}{ Tumour vascularity } \\
\hline \multicolumn{10}{|l|}{ Tumour status } \\
\hline T2 & 59.9 & 45.5 & 0.4792 & 45.0 & 57.2 & 0.5120 & 40.0 & 62.5 & 0.0106 \\
\hline T3 & 0.0 & 25.0 & $0.774 \mid$ & 0.0 & 33.3 & 0.0389 & 0.0 & 50.0 & 0.4547 \\
\hline T4 & 40.4 & 24.1 & 0.2268 & 60.0 & 22 & 0.0909 & 31.8 & 37.9 & 0.9706 \\
\hline $\mathrm{NI}, \mathrm{N} 2, \mathrm{~N} 3$ & 31.1 & 25.2 & 0.2680 & 24.2 & 27.7 & 0.6718 & 26.3 & 26.5 & 0.2061 \\
\hline \multicolumn{10}{|l|}{ Pathological stage } \\
\hline Stage I & 78.4 & 65.6 & 0.3910 & 74.9 & 72.9 & 0.6786 & 70.4 & 77.8 & 0.3797 \\
\hline Stage ॥ & 50.0 & 40.0 & 0.6728 & 33.3 & 45.5 & 0.4972 & 25.0 & 66.7 & 0.1021 \\
\hline Stage IIIA & 21.4 & 20.0 & 0.4972 & 18.8 & 22.2 & 0.4935 & 22.2 & 16.7 & 0.2155 \\
\hline Stage IIIB & 40.4 & 24.1 & 0.2268 & 53.6 & 25.9 & 0.2244 & 31.8 & 37.9 & 0.9706 \\
\hline \multicolumn{10}{|l|}{ Differentiation } \\
\hline Squamous cell carcinoma & 68.3 & 50.4 & 0.1619 & 60.0 & 58.0 & $0.498 \mid$ & 44.1 & 68.3 & 0.0349 \\
\hline Large cell carcinoma & 50.0 & 30.0 & 0.4934 & 0.0 & 55.6 & 0.0013 & 14.3 & 57.1 & 0.0535 \\
\hline Total & 64.4 & 45.4 & 0.0146 & 59.6 & 54.0 & 0.6596 & 50.8 & 62.2 & 0.0378 \\
\hline
\end{tabular}


A

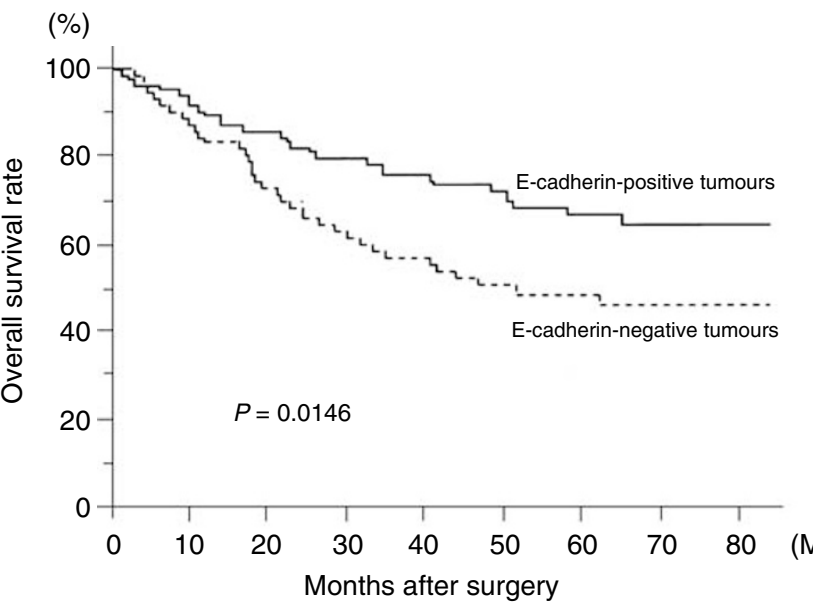

C

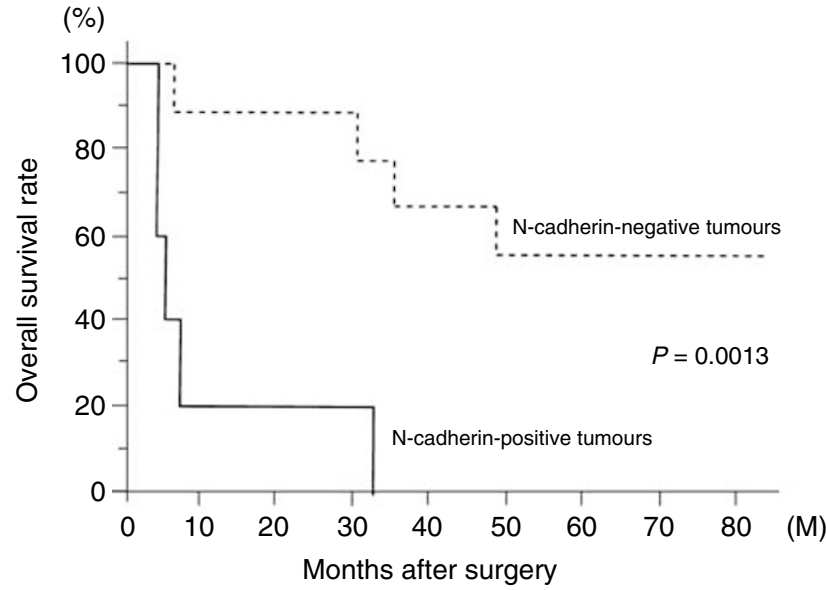

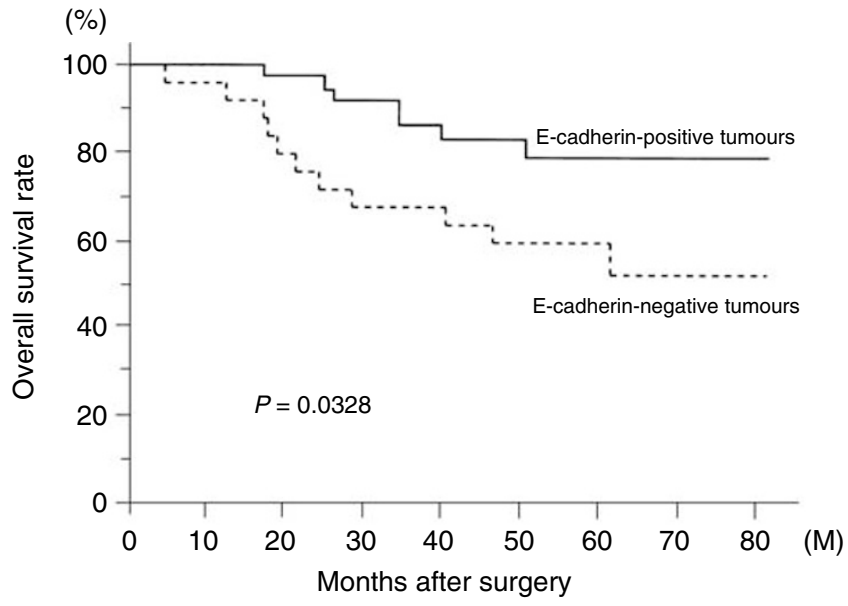

D

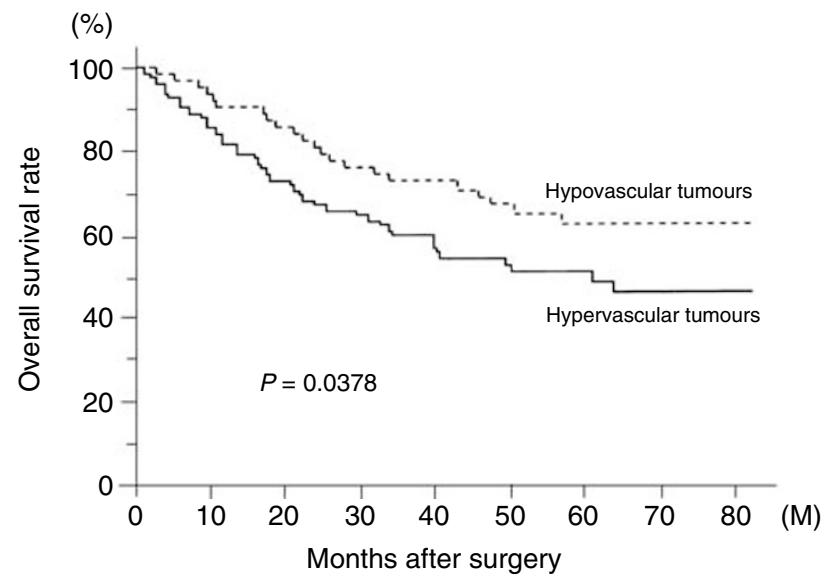

Figure 3 (A) Overall survival of I 50 patients with NSCLC in relation to their E-cadherin status. (B) Overall survival of 62 patients with TI NSCLC in relation to their E-cadherin status. (C) Overall survival of 14 patients with large cell carcinoma in relation to their $\mathrm{N}$-cadherin status. (D) Overall survival of 150 patients with NSCLC in relation to their tumour vascularity.

Table 3 Multivariate regression analysis in predicting survival of I 50 NSCLC patients

\begin{tabular}{|c|c|c|c|c|c|c|c|c|c|}
\hline \multirow{2}{*}{$\begin{array}{l}\text { Histology } \\
\text { Variables }\end{array}$} & \multirow[b]{2}{*}{$\begin{array}{l}\text { Assigned } \\
\text { score }\end{array}$} & \multicolumn{2}{|c|}{ Non-small-cell lung cancer } & \multicolumn{2}{|c|}{ Adenocarcinoma } & \multicolumn{2}{|c|}{ Squamous cell carcinoma } & \multicolumn{2}{|c|}{ Large cell carcinoma } \\
\hline & & $\begin{array}{c}\text { Hazard } \\
\text { ratio }\end{array}$ & $P$-value & $\begin{array}{l}\text { Hazard } \\
\text { ratio }\end{array}$ & $P$-value & $\begin{array}{c}\text { Hazard } \\
\text { ratio }\end{array}$ & $P$-value & $\begin{array}{c}\text { Hazard } \\
\text { ratio }\end{array}$ & $P$-value \\
\hline \multicolumn{10}{|l|}{ E-cadherin } \\
\hline Positive & 0 & 1.736 & 0.0339 & 1.389 & 0.3503 & 2.662 & 0.0912 & 0.111 & 0.2586 \\
\hline Negative & I & & & & & & & & \\
\hline \multicolumn{10}{|l|}{ Tumour vascularity } \\
\hline Hypovascular & 0 & 1.785 & 0.0295 & 1.121 & 0.7693 & 5.529 & 0.0053 & 24.815 & 0.0312 \\
\hline $\mathrm{TI}$ & 1 & 1.399 & 0.0013 & 1.352 & 0.0194 & 1.756 & 0.0816 & 7.020 & 0.0374 \\
\hline $\mathrm{T} 2$ & 2 & & & & & & & & \\
\hline T3 & 3 & & & & & & & & \\
\hline $\mathrm{T} 4$ & 4 & & & & & & & & \\
\hline \multicolumn{10}{|l|}{ Nodal status } \\
\hline No & 0 & 1.829 & $<0.0001$ & 1.719 & 0.0007 & 2.916 & 0.0162 & 15.526 & 0.0160 \\
\hline \multicolumn{10}{|l|}{ Smoking } \\
\hline$<60$ & 0 & 0.898 & 0.7386 & 0.681 & 0.3459 & 2.034 & 0.5356 & 19.941 & 0.0530 \\
\hline$\geqslant 60$ & । & & & & & & & & \\
\hline
\end{tabular}


NSCLCs, also have demonstrated that dysfunction of E-cadherin/ catenin complex is associated with dedifferentiation (Bohm et al, 1994), lymph node metastasis (Sulzer et al, 1998), and a poor prognosis (Sulzer et al, 1998). The present study has also revealed that decreased expression of E-cadherin is associated with lymph node metastasis and a poor prognosis in NSCLC patients. Thus, Ecadherin acts as a metastatic suppressor gene in human NSCLCs.

Consistent with these results, E-cadherin promotes tight cellcell adhesion in a zipper-like fashion, restricting cell movement. On the other hand, recent experimental studies have demonstrated that $\mathrm{N}$-cadherin could promote a dynamic adhesion state. Neuralcadherin is responsible for the interaction between endothelial cells and other surrounding cell types expressing $\mathrm{N}$-cadherin such as vascular smooth muscle cells and pericytes (Navarro et al, 1998). This kind of adhesion of N-cadherin was suggested to play important roles in various biological behaviours, including morphogenesis (Takeichi, 1991) and angiogenesis (Gerhardt et al, 1999, 2000) during development and epithelial-mesenchymal transition during tumour progression (Islam et al, 1996; Tran et al, 1999).

With respect to tumour progression, $\mathrm{N}$-cadherin expression could mediate an epithelial-mesenchymal transition and angiogenesis. At first, the epithelial-mesenchymal transition is associated with typical for some carcinoma cells late in tumour progression and correlated with metastatic potential (Birchmeier et al, 1996). In an experimental study, transfection of antisense $\mathrm{N}$-cadherin into a cancer cell line with a scattered fibroblastic phenotype resulted in reversion to a normal-appearing squamous epithelial cell, interestingly, with increased E-cadherin expression (Islam et al, 1996). In addition, transfection of $\mathrm{N}$-cadherin into a normal-appearing squamous epithelial cell line resulted in a scattered fibroblastic phenotype, with downregulation of Ecadherin. Another study also revealed that a N-cadherin-positive carcinoma cell line displayed an invasive potential after intraperitoneal injection into SCID mice (Tran et al, 1999).

Recently, basic studies have shown the presence of the interactions between N-cadherin and fibroblast growth factor (FGF) receptor (Doherty and Walsh, 1996; Saffell et al, 1997). Hazan et al. (2000) demonstrated that treatment with FGF-2 induced $\mathrm{N}$-cadherin-expressing breast carcinoma cells into a more invasive phenotype, with upregulation of matrix metalloproteinase MMP-9. Other experimental studies have also shown that transfection of $\mathrm{N}$-cadherin can promote motility in human cancer cell lines (Nieman et al, 1999; Li et al, 2001).

On the other hand, $\mathrm{N}$-cadherin expression was reported to mediate angiogenesis during development. $\mathrm{N}$-cadherin-expressing cells can interact with $\mathrm{N}$-cadherin-expressing vascular endothelial cells during development (Gerhardt et al, 1999, 2000). Then, the interaction of N-cadherin and FGF receptor promotes the FGF-2 signal pathway, which was reported to induce vascular endothelial growth factor expression (Seghezzi et al, 1998). Therefore, $\mathrm{N}$ cadherin-expressing tumour cells might induce angiogenesis through the interaction with $\mathrm{N}$-cadherin-expressing vascular endothelial cells during tumour progression. In addition, the tumour angiogenesis is also essential to tumour growth and metastasis (Folkman, 1990, 1995).
Despite of the accumulation of these results regarding $\mathrm{N}$ cadherin, only a few clinical studies on $\mathrm{N}$-cadherin expression in human cancers were reported (Soler et al, 1997; Yanagimoto et al, 2001). Therefore, we performed the present clinical study on the expression of N-cadherin and E-cadherin in NSCLC patients.

At first, our present study revealed that $\mathrm{N}$-cadherin expression in NSCLCs is significantly associated with tumour vascularity. This is the first clinical report demonstrating a correlation between $\mathrm{N}$-cadherin expression and angiogenesis in human cancers. Especially, the frequencies of hypervascular tumours in $\mathrm{N}$ cadherin-expressing tumours were likely to be higher than that in $\mathrm{N}$-cadherin-negative tumours, among squamous cell carcinoma (50.0 vs $30.0 \%$ ), and among large cell carcinoma (60.0 vs $44.4 \%)$. In addition, of the large cell carcinomas, the frequency of $\mathrm{N}$-cadherinpositive tumours was likely to be greater in E-cadherin-negative tumours than in E-cadherin-positive tumours (40.0 vs 25.0\%). Furthermore, among the large cell carcinomas, survival of patients with $\mathrm{N}$-cadherin-positive tumours was significantly lower than that of patients with $\mathrm{N}$-cadherin-negative tumours. However, there was no significant correlation between $\mathrm{N}$-cadherin status and lymph node metastasis.

These results might suggest that in some populations of NSCLCs, from well-differentiated squamous cell carcinomas to undifferentiated large cell carcinomas, inactivation of E-cadherin is an early event in the tumour progression, and activation of the inappropriate cadherin, such as N-cadherin, would be a subsequent event, which could promote angiogenesis and poor survival. This concept of cadherin switching (Cavallaro et al, 2002) has been reported in some kinds of human cancers, such as melanoma (Hsu et al, 1996) and prostate cancer (Tomita et al, 2000). In the present study, however, there was no significant inverse correlation between E-cadherin expression and $\mathrm{N}$-cadherin. This might be partly because undifferentiated carcinoma is relatively rare among NSCLCs.

On the other hand, there was no such a relation regarding $\mathrm{N}$ cadherin expression in adenocarcinomas. Thus, different cellular mechanisms might be responsible in the progression of squamous cell carcinomas and adenocarcinomas (Bohm et al, 1994). In the present study, although tumour vascularity was a significant prognostic factor both in patients with squamous cell carcinoma and in patients with large cell carcinoma, there was no significant difference in the survival of patients with adenocarcinoma in relation to tumour vascularity. This finding might be partly because most of adenocarcinomas were hypervascular. In addition, reduced expression of integrin, another kind of adhesion molecules, is associated with the prognosis of patients with adenocarcinoma of the lung (Adachi et al, 1998).

In conclusion, the present study of NSCLC patients has demonstrated that E-cadherin expression and tumour vascularity are significant prognostic factors of NSCLC patients. Furthermore, $\mathrm{N}$-cadherin expression is associated with tumour angiogenesis, and its expression is one of the prognostic factors of patients with undifferentiated large cell carcinomas. Thus, N-cadherin also might play a specific role in NSCLCs, especially in undifferentiated large cell carcinomas.

\section{REFERENCES}

Aberle H, Schwartz H, Kemler R (1996) Cadherin - catenin complex: protein interactions and their implications for cadherin function. J Cell Biochem 61: $514-523$

Adachi M, Taki T, Huang C, Higashiyama M, Doi O, Tsuji T, Miyake M (1998) Reduced integrin $\alpha 3$ expression as a factor of poor prognosis of patients with adenocarcinoma of the lung. J Clin Oncol 16: $1060-1067$
Birchmeier C, Birchmeier W, Brand-Saberi B (1996) Epithelial-mesenchymal transition in cancer progression. Acta Anat 156: 217-226

Blaschuk OW, Munro S, Farookhi R (1995) Cadherins, steroids and cancer. Endocrine 3: 83-89

Blaschuk OW, Rowlands TM (2000) Cadherins as modulators of angiogenesis and the structural integrity of blood vessels. Cancer Metastasis Rev 19: $1-5$ 
Bohm M, Totzeck B, Birchmeier W, Wieland I (1994) Differences of Ecadherin expression levels and patterns in primary and metastatic human lung cancer. Clin Exp Metastasis 12: 55-62

Cavallaro U, Schaffhauser B, Christofori G (2002) Cadherins and the tumour progression: is it all in a switch? Cancer Lett 176: 123-128

Cordon-Cardo C (1995) Mutation of cell cycle regulators: biological, clinical implications for human neoplasia. Am J Pathol 147: 545-560

Doherty P, Walsh FS (1996) CAM-FGF receptor interactions: a model for axonal growth. Mol Cell Neurosci 8: 99-111

Frixen UH, Behrens J, Sachs M, Eberle G, Voss B, Warda A, Lochner D, Birchmeier W (1991) E-cadherin-mediated cell-cell adhesion prevents invasiveness of human carcinoma cells. J Cell Biol 113: 173-185

Folkman J (1990) What is the evidence that tumours are angiogenesis dependent. J Natl Cancer Inst 82: 4-6

Folkman J (1995) Angiogenesis in cancer, vascular, rheumatoid and other disease. Nat Med 1: 27-31

Gerhardt H, Liebner S, Redies C, Wolburg H (1999) N-cadherin expression in endothelial cells during early angiogenesis in the eye and brain of the chicken: relation to blood - retina and blood - brain barrier development. Eur J Neurosci 11: $1191-1201$

Gerhardt H, Wolburg H, Redies C (2000) N-cadherin mediates pericyticendothelial interaction during brain angiogenesis in the chicken. Dev Dynamics 218: $472-479$

Hazan RB, Phillips GR, Qiao RF, Norton L, Aaronson SA (2000) Exogenous expression of $\mathrm{N}$-cadherin in breast cancer cells induces cell migration, invasion, and metastasis. I Cell Biol 148: 779-790

Hatta K, Takeichi M (1986) Expression of N-cadherin adhesion molecules associated with early morphogenetic events in chick development. Nature 320: $447-449$

Hatta K, Takagi S, Fujisawa H, Takeichi M (1987) Spatial and temporal expression pattern of $\mathrm{N}$-cadherin cell adhesion molecules correlated with morphogenetic processes of chicken embryos. Dev Biol 120: $215-227$

Hsu MY, Wheelock MJ, Johnson KR, Herlyn M (1996) Shifts in cadherin profiles between human normal melanocytes and melanomas. J Invest Dermatol Symp Proc 1: 188-194

Islam S, Carey TE, Wolf GT, Wheelock MJ, Johnson KR (1996) Expression of N-cadherin by human squamous carcinoma cells induces a scattered fibroblastic phenotype with disrupted cell-cell adhesion. J Cell Biol 135: $1643-1654$

Li G, Satyamoorthy K, Herlyn M (2001) N-cadherin-mediated intercellular interactions promote survival and migration of melanoma cells. Cancer Res 61: 3819-3825

Liu D, Huang C, Kameyama K, Hayashi E, Yamauchi A, Kobayashi S, Yokomise H (2001) E-cadherin expression associated with differentiation and prognosis in non-small-cell lung cancer patients. Ann Thorac Surg 71: $949-955$

Matsuyama K, Chiba Y, Sasaki M, Tanaka H, Muraoka R, Tanigawa N (1998) Tumour angiogenesis as a prognostic marker in operable nonsmall cell lung cancer. Ann Thorac Surg 65: 1405-1409

Mbalaviele G, Dunstan CR, Sasaki A, Williams PJ, Mundy GR, Yoneda T (1996) E-cadherin expression in human breast cancer cells suppresses the development of osteolytic bone metastases in an experimental metastasis model. Cancer Res 56: $4063-4070$

Navarro P, Ruco L, Dejana E (1998) Differential localization of VE- and $\mathrm{N}$-cadherins in human endothelial cells: VE-cadherin competes with $\mathrm{N}$-cadherin for junctional localization. I Cell Biol 140: 1475 - 1484

Nawrocki B, Polette M, van Hengel J, Tournier JM, van Roy F, Birembaut P (1998) Cytoplasmic redistribution of E-cadherin-catenin adhesion complex is associated with down-regulated tyrosine phosphorylation of E-cadherin in human bronchopulmonary carcinoma. Am J Pathol 153: $1521-1530$

Nieman MT, Prudoff RS, Johnson KR, Wheelock MJ (1999) N-cadherin promotes motility in human breast cancer cells regardless of their Ecadherin expression. J Cell Biol 147: 631-643

Pignatelli M, Vessey CJ (1994) Adhesion molecules: novel molecular tools in tumour pathology. Hum Pathol 25: 849-856

Saffell JL, Williams EJ, Mason IJ, Walsh FS, Doherty P (1997) Expression of a dominant negative FGF receptor inhibits axonal growth and FGF receptor phosphorylation stimulated by CAMs. Neuron 18: $231-242$

Seghezzi G, Patel S, Ren CJ, Gualandris A, Pintucci G, Robbins ES, Shapiro RL, Galloway AC, Rifkin DB, Mignatti P (1998) Fibroblast growth factor2 (FGF-2) induces vascular endothelial growth factor (VEGF) expression in the endothelial cells of forming capillaries: an autocrine mechanism contributing to angiogenesis. J Cell Biol 141: 1659-1673

Shibanuma H, Hirano T, Tsuji K, Wu Q, Shrestha B, Konaka C, Ebihara Y, Kato $\mathrm{H}$ (1998) Influence of E-cadherin dysfunction upon local invasion and metastasis in nonsmall cell lung cancer. Lung Cancer 22: $85-95$

Soler AP, Knudsen KA, Tecson-Miguel A, McBrearty FX, Han AC, Salazar H (1997) Expression of E-cadherin and N-cadherin in surface epithelial stromal tumours of the ovary distinguishes mucinous from serous and endometrioid tumours. Hum Pathol 28: $734-739$

Sulzer MA, Leers MP, van Noord JA, Bollen EC, Theunissen PH (1998) Reduced E-cadherin expression is associated with increased lymph node metastasis and unfavorable prognosis in nonsmall cell lung cancer. Am J Respir Crit Care Med 157: 1319-1323

Takeichi M (1990) Cadherins: a molecular family important in selective cell-cell adhesion. Ann Rev Biochem 59: 237-252

Takeichi M (1991) Cadherin cell adhesion receptors as a morphogenetic regulator. Science 251: $1451-1455$

Tomita K, van Bokhoven A, van Leenders GJLH, Ruijter ETG, Jansen CFJ, Bussemakers MJG, Schalken JA (2000) Cadherin switching in human prostate cancer progression. Cancer Res 60: 3650-3654

Tran NL, Nagle RB, Cress AE, Heimark RL (1999) N-cadherin expression in human prostate carcinoma cell lines. Am J Pathol 155: 787-798

Travis WD, Colby TV, Corrin B, Shimosato Y, Brambilla E (1999) World Health Organization International Histological Classification of Tumours: Histological Typing of Lung and Pleural Tumours, 1.3.4. Berlin Heidelberg, Germany: Springer-Verlag

Yanagimoto K, Sato Y, Shimoyama Y, Tsuchiya B, Kuwao S, Kameya T (2001) Co-expression of $\mathrm{N}$-cadherin and $\alpha$-fetoprotein in stomach cancer. Pathol Int 51: 612-618 